\title{
Pharmacogenetics of Cannabinoids
}

\author{
Szymon Hryhorowicz $^{1} \cdot$ Michal Walczak $^{1}$ - Oliwia Zakerska-Banaszak ${ }^{1}$. \\ Ryszard Słomski $^{1,2} \cdot$ Marzena Skrzypczak-Zielińska $^{1}$
}

Published online: 22 May 2017

(C) The Author(s) 2017. This article is an open access publication

\begin{abstract}
Although the application of medical marijuana and cannabinoid drugs is controversial, it is a part of modern-day medicine. The list of diseases in which cannabinoids are promoted as a treatment is constantly expanding. Cases of significant improvement in patients with a very poor prognosis of glioma or epilepsy have already been described. However, the occurrence of side effects is still difficult to estimate, and the current knowledge of the therapeutic effects of cannabinoids is still insufficient. In our opinion, the answers to many questions and concerns regarding the medical use of cannabis can be provided by pharmacogenetics. Knowledge based on proteins and molecules involved in the transport, action, and metabolism of cannabinoids in the human organism leads us to predict candidate genes which variations are responsible for the presence of the therapeutic and side effects of medical marijuana and cannabinoid-based drugs. We can divide them into: receptor genes-CNR1, CNR2, TRPV1, and GPR55, transporters-ABCB1, $A B C G 2$, $S L C 6 A$, biotransformation, biosynthesis, and bioactivation proteins encoded by CYP3A4, CYP2C19, CYP2C9, CYP2A6, CYPIA1, COMT, FAAH, COX2, ABHD6, $A B H D 12$ genes, and also MAPK14. This review organizes the current knowledge in the context of cannabinoids pharmacogenetics according to individualized medicine and cannabinoid drugs therapy.
\end{abstract}

Szymon Hryhorowicz

szymon.hryhorowicz@igcz.poznan.pl

1 Institute of Human Genetics, Polish Academy of Sciences, Strzeszynska 32, 60-479 Poznan, Poland

2 Department of Biochemistry and Biotechnology, University of Life Sciences, Dojazd 11, 60-632 Poznan, Poland

\section{Key Points}

Cannabinoids have many side effects and adverse drug reactions.

Robust genetic associations with cannabinoids efficacy and adverse effects have not yet been studied extensively.

Single nucleotide polymorphism in the $C N R 1$ gene and marijuana addiction is the most studied; however, the results of various studies are still not conclusive.

\section{Introduction}

Complexity of the cannabinoid pathway, as well as individual genetic predispositions in the population, can lead to various body responses on the cannabinoids treatment. It has been considered that long-term use of cannabis may be a risk factor for psychosis and neurocognitive disorders [1-3]. Short-term application may result in an increase in non-serious adverse events [4].

The patient's response to cannabinoid treatment may have a genetic background, which depends on genes polymorphism involved in the action, metabolism, and the transport of these substances in the organism. Based on the cannabinoid distribution and activity mechanism as well as proteins involved in their biotransformation, a set of candidate genes can be chosen which variants may determine the therapeutic effect and also the occurrence of possible 
side effects and adverse reactions. We can divide them into the following groups and contain genes encoding receptors-CNR1, CNR2, TRPV1, GPR55, OPRM1, and GABRA2; transporters and action-ABCB1, $A B C G 2$, $S L C 6 A 4$, and COMT; enzymes involved in the metabolism of cannabinoids-CYPs and UGTs; biosynthesis, and bioactivation of endocannabinoids: FAAH, MAGL, COX2, $A B H D 6$, and $A B H D 12$; and cannabinoid-related cellular processes: MAPK14.

This work systematizes and sums up the state of current knowledge in the field of pharmacogenetics of cannabinoids according to cannabinoids therapy and personalized medicine.

\section{Methods of Literature Search}

Papers published until February 2017 was included. Publication search was performed in Medline and PubMed database. The keywords: cannabinoids polymorphisms, cannabinoids candidate genes, cannabis, medical cannabis, and addiction were used.

\section{Gene Variants vs Cannabinoids Use}

As mentioned above, the effect of cannabis can be dependent on pharmacogenetic factors. Below, we discuss the current data according to genes polymorphisms which are involved in transport, action, and biotransformation of cannabinoids (Table 1).

\subsection{Receptor Genes}

\subsubsection{CNR1 and CNR2}

In 1990 and in 1993, the first and second cannabinoid receptors (CB1, CB2) were identified and cloned, which contributed to a significant increase in the understanding of cannabinoids. The CB1 receptor, encoded by the CNR1 gene (cannabinoid receptor type 1, OMIM: 114610) [5], is located on the human chromosome 6q14-15 and consists of four exons, of which the latter is the largest and most commonly expressed in brain tissue [6]. Evolutionary conservatism is a characteristic feature of the CB1 receptor. It has been observed that amino acid sequences are similar in humans, mice, and rats to a degree of $97-99 \%$ [7]. Activation of the $\mathrm{CB}$ receptor stimulates the appetite and has antiemetic, analgesic, and sedative effects [8]. Association studies between the occurrence of single nucleotide polymorphism (SNP) in the CNRI gene and marijuana addiction, also including the trinucleotide repeat locus $(\mathrm{AAT})_{n}$ and insertion-deletion $(-3180 \mathrm{~T})$ polymorphism, revealed contradictory results [9]. Comings et al. showed a correlation between $(\mathrm{AAT})_{>5}$ repeats with drug dependence in 206 non-Hispanic Caucasians (92 subjects and 114 controls) [10], but most studies on trinucleotide repeats $(\mathrm{AAT})_{n}$ demonstrated negative results [11-13].

In an investigation performed on the group of 1923 individuals, a correlation of two SNPs in CNR1 gene rs806368 $(p=0.05)$ and rs806380 $(p=0.009)$ with cannabis dependence were identified [9]. Haplotype analysis revealed stronger association by rs 806380 [9]. In turn, Hopfer and his group analyzed five SNPs variants (rs2273512, rs6454674, rs806380, rs806377, and rs104935) in CNRl gene and demonstrated that rs806380 was significantly associated with cannabis dependence symptoms [14]. However, Herman et al. have not confirmed these observations [15]. The same conclusions were reached by Australian and American researchers [16, 17]. Moreover, Hartman group showed an association $(p=0.029)$, of rs1049353 in the CNR1 gene with cannabis dependence symptoms in case-control samples $(n=224)$ [17]. On the other hand, Bühler et al. indicated non-statistically significant correlation of CNR1 rs1049353, rs806368, rs6454674, and rs 7766029 with cannabis use in a group composed of young individuals $(n=91)$ [18]. In case of rs806368, Zuo and co-workers analyzed 451 healthy control subjects and 550 substance dependence (including European Americans and African Americans) and showed that substance dependence increased with the number of $\mathrm{G}$ alleles in European Americans significantly [19]. In studies of rs2023239 CNRI gene variant among 105 daily marijuana smokers-students from the University of Colorado were tested [20]. Participants with CT or CC genotype were more susceptible to the negative impact of the cannabinoids action (greater withdrawal, negative affect, and higher levels of craving to smoke more). Moreover, heterozygous had 20\% higher marijuana dependence checklist scores than TT subjects [20]. Di Marzo et al. demonstrated that marijuana abuse by carriers of the c. $* 2394 \mathrm{~A}>\mathrm{G}(\mathrm{rs} 12720071)$ variant of the $C N R 1$ gene contributes to deficits in the volume of white matter in the brains of schizophrenia patients [8].

The second gene selected through GWAS is CNR2 encoding CB2 (OMIM: 605051). It has been actively investigated for its role in osteoporosis, inflammatory responses, leukemia, and certain forms of cancer. However, investigations on the $C N R 2$ gene in the context of addiction are rarely described in the literature. The Ishiguro research group showed a link between the polymorphism c.188A $>\mathrm{G}$ (p.Gln63Arg, rs2501432) and alcohol dependence in the Japanese population [21]. In turn, Carrasquer et al. introduced Gln63Arg, His316Tyr, and Gln63Arg/His316 mutations in recombinant human CB2 receptors. Mutant 
Table 1 Association of genetic variants with response to cannabinoids

\begin{tabular}{|c|c|c|c|c|c|c|c|}
\hline \multirow[t]{2}{*}{ Function } & \multirow[t]{2}{*}{ Gene } & \multicolumn{3}{|c|}{ Genetic variant } & \multirow[t]{2}{*}{ Study group } & \multirow[t]{2}{*}{ Effect } & \multirow[t]{2}{*}{ Reference } \\
\hline & & $\begin{array}{l}\text { RefSNP } \\
\text { number } \\
\text { rs }\end{array}$ & $\begin{array}{l}\text { Nucleotide } \\
\text { change }\end{array}$ & $\begin{array}{l}\text { Amino } \\
\text { acid } \\
\text { change }\end{array}$ & & & \\
\hline \multirow[t]{18}{*}{ Receptor } & \multirow[t]{17}{*}{ CNR1 } & \multirow[t]{4}{*}{806380} & \multirow[t]{4}{*}{ c. $-63-9597 \mathrm{~T}>\mathrm{C}$} & \multirow[t]{4}{*}{ Intron } & $\begin{array}{l}379 \text { cases } \\
(\mathrm{EA}, \mathrm{AA})\end{array}$ & Cannabis dependence & [9] \\
\hline & & & & & $\begin{array}{l}327 \text { cases } \\
(\mathrm{CS}, \mathrm{H}, \mathrm{AA})\end{array}$ & Cannabis dependence & [14] \\
\hline & & & & & $\begin{array}{l}91 \text { students } \\
(\mathrm{CS})\end{array}$ & $\begin{array}{l}\text { No association with drug } \\
\text { consumption }\end{array}$ & {$[18]$} \\
\hline & & & & & $\begin{array}{l}7452 \text { subjects } \\
(\mathrm{CS})\end{array}$ & $\begin{array}{l}\text { No association with } \\
\text { cannabis use }\end{array}$ & [16] \\
\hline & & 806379 & c. $-63-6211 \mathrm{~T}>\mathrm{A}$ & Intron & $\begin{array}{l}92 \text { cases } \\
(\mathrm{EA}, \mathrm{AA})\end{array}$ & $\begin{array}{l}\text { No association with } \\
\text { cannabis dependence }\end{array}$ & [15] \\
\hline & & \multirow[t]{2}{*}{806368} & \multirow[t]{2}{*}{ c. $* 3475 \mathrm{~A}>\mathrm{G}$} & \multirow[t]{2}{*}{$3^{\prime}$ UTR } & $\begin{array}{l}7452 \text { subjects } \\
(\mathrm{CS})\end{array}$ & $\begin{array}{l}\text { No association with } \\
\text { cannabis use }\end{array}$ & [16] \\
\hline & & & & & $\begin{array}{l}550 \text { cases with drug/ } \\
\text { alcohol } \\
\text { dependence and } \\
451 \text { controls, } \\
\text { (EA, AA) }\end{array}$ & Influence drug dependence & [19] \\
\hline & & \multirow[t]{2}{*}{1535255} & \multirow[t]{2}{*}{ c. $-63-6152 \mathrm{~A}>\mathrm{C}$} & \multirow[t]{2}{*}{ Intron } & $\begin{array}{l}92 \text { cases } \\
(\mathrm{EA}, \mathrm{AA})\end{array}$ & $\begin{array}{l}\text { No association with } \\
\text { cannabis dependence }\end{array}$ & [15] \\
\hline & & & & & $\begin{array}{l}7452 \text { subjects } \\
(\mathrm{CS})\end{array}$ & $\begin{array}{l}\text { No association with } \\
\text { cannabis use }\end{array}$ & [16] \\
\hline & & 6928499 & c. $-63-6233 \mathrm{C}>\mathrm{G}$ & Intron & $\begin{array}{l}92 \text { cases } \\
(\mathrm{EA}, \mathrm{AA})\end{array}$ & $\begin{array}{l}\text { No association with } \\
\text { cannabis dependence }\end{array}$ & [15] \\
\hline & & 2023239 & c. $-63-5426 A>G$ & Intron & $\begin{array}{l}92 \text { cases } \\
(\mathrm{EA}, \mathrm{AA})\end{array}$ & $\begin{array}{l}\text { No association with } \\
\text { cannabis dependence }\end{array}$ & [15] \\
\hline & & \multirow[t]{4}{*}{-} & \multirow[t]{4}{*}{$(\mathrm{AAT}) n$ repeats } & \multirow[t]{4}{*}{$\begin{array}{r}3^{\prime} \text { near } \\
\text { gene }\end{array}$} & $\begin{array}{l}92 \text { cases and } 114 \\
\text { controls } \\
(\mathrm{CS})\end{array}$ & $\begin{array}{l}(\mathrm{AAT})_{>5} \text { associated with drug } \\
\text { dependence }\end{array}$ & [13] \\
\hline & & & & & $\begin{array}{l}529 \text { cases } \\
(\mathrm{EA}, \mathrm{AA})\end{array}$ & $\begin{array}{l}\text { No association with } \\
\text { drug- or alcohol dependence }\end{array}$ & {$[10]$} \\
\hline & & & & & $\begin{array}{l}375 \\
\text { Chinese }\end{array}$ & $\begin{array}{l}\text { No association with } \\
\text { heroin abuse }\end{array}$ & [11] \\
\hline & & & & & $\begin{array}{l}40 \text { subjects } \\
(\mathrm{CS})\end{array}$ & $\begin{array}{l}\text { No association with drug use } \\
\text { and drug abuse }\end{array}$ & [12] \\
\hline & & 1049353 & c. $1359 \mathrm{G}>\mathrm{A}$ & Thr453= & $\begin{array}{l}224 \text { cases, } 108 \\
\text { controls } \\
(\mathrm{CS}, \mathrm{H})\end{array}$ & $\begin{array}{l}\text { Association with cannabis } \\
\text { dependence symptoms for } \\
\text { CSS }\end{array}$ & [17] \\
\hline & & 6454674 & $-64+1046 \mathrm{~T}>\mathrm{G}$ & Intron & $\begin{array}{l}550 \text { cases, } 451 \\
\text { controls } \\
(\mathrm{EA}, \mathrm{AA})\end{array}$ & Influence drug dependence & [19] \\
\hline & $C N R 2$ & $\begin{array}{l}2501432 \\
2229579\end{array}$ & $\begin{array}{l}188 \mathrm{~A}>\mathrm{G} \\
946 \mathrm{C}>\mathrm{T}\end{array}$ & $\begin{array}{l}\text { Gln63Arg } \\
\text { His316Tyr }\end{array}$ & HEK293 cells & $\begin{array}{l}\text { Alterations in the CB2 receptor } \\
\text { functions }\end{array}$ & [22] \\
\hline Transport & $A B C B 1$ & 1045642 & $3435 \mathrm{C}>\mathrm{T}$ & Ile1145Ile & $\begin{array}{l}40 \text { cases, } 40 \text { controls } \\
\text { (CS) }\end{array}$ & $\begin{array}{l}\text { CC genotype associated with } \\
\text { cannabis dependence } \\
p=0.045, \mathrm{OR}=6.61 \\
(1.05-46.58)\end{array}$ & [37] \\
\hline
\end{tabular}


Table 1 continued

\begin{tabular}{|c|c|c|c|c|c|c|c|}
\hline \multirow[t]{2}{*}{ Function } & \multirow[t]{2}{*}{ Gene } & \multicolumn{3}{|c|}{ Genetic variant } & \multirow[t]{2}{*}{ Study group } & \multirow[t]{2}{*}{ Effect } & \multirow[t]{2}{*}{ Reference } \\
\hline & & $\begin{array}{l}\text { RefSNP } \\
\text { number } \\
\text { rs }\end{array}$ & $\begin{array}{l}\text { Nucleotide } \\
\text { change }\end{array}$ & $\begin{array}{l}\text { Amino } \\
\text { acid } \\
\text { change }\end{array}$ & & & \\
\hline \multirow[t]{7}{*}{ Biotranformation } & \multirow[t]{3}{*}{$F A A H$} & \multirow[t]{3}{*}{324420} & \multirow[t]{3}{*}{$385 \mathrm{C}>\mathrm{A}$} & \multirow[t]{3}{*}{ Pro129Thr } & 1737 subjects & $\begin{array}{l}\text { A/A genotype associated with } \\
\text { drug drug use, abuse }\end{array}$ & {$[60]$} \\
\hline & & & & & $\begin{array}{l}745 \text { subjects } \\
(\mathrm{CS})\end{array}$ & $\begin{array}{l}\text { No association with risk for } \\
\text { alcohol or tobacco use }\end{array}$ & {$[57]$} \\
\hline & & & & & $\begin{array}{l}105 \text { students at the } \\
\text { University of } \\
\text { Colorado }\end{array}$ & $\begin{array}{l}\text { No association in marijuana } \\
\text { smokers for dependence }\end{array}$ & {$[20]$} \\
\hline & \multirow[t]{4}{*}{ COMT } & \multirow[t]{4}{*}{4680} & \multirow[t]{4}{*}{$472 \mathrm{~A}>\mathrm{G}$} & \multirow[t]{4}{*}{ Val158Met } & $\begin{array}{l}42 \text { cases and } 32 \\
\text { controls, } \\
\text { (European-CS) }\end{array}$ & $\begin{array}{l}\text { Impact of THC on memory and } \\
\text { sustained attention }\end{array}$ & {$[40]$} \\
\hline & & & & & $\begin{array}{l}86 \text { cannabis users } \\
\text { and } 58 \text { non-drug } \\
\text { users, (European- } \\
\text { CS) }\end{array}$ & $\begin{array}{l}\text { Moderate the impact of } \\
\text { cannabis use on executive } \\
\text { functions }\end{array}$ & {$[39]$} \\
\hline & & & & & 56 subjects & $\begin{array}{l}\text { Association between cannabis } \\
\text { and psychotic phenomena }\end{array}$ & [45] \\
\hline & & & & & 803 individuals & $\begin{array}{l}\text { Psychotic symptoms and to } \\
\text { developing schizophrenia } \\
\text { form disorder in cannabis } \\
\text { users }\end{array}$ & {$[46]$} \\
\hline \multirow[t]{4}{*}{ Others } & \multirow[t]{2}{*}{$G A B R A 2$} & \multirow[t]{2}{*}{ rs279858 } & \multirow[t]{2}{*}{$231 \mathrm{~A}>\mathrm{G}$} & \multirow[t]{2}{*}{ Lys132= } & $\begin{array}{l}1227 \\
(\mathrm{CS}, \mathrm{AA})\end{array}$ & $\begin{array}{l}\text { Association with marijuana } \\
\text { dependence }\end{array}$ & {$[33]$} \\
\hline & & & & & 4597 subjects & $\begin{array}{l}\text { No association in frequency of } \\
\text { cannabis use }\end{array}$ & {$[30]$} \\
\hline & OPRM1 & 1799971 & $118 \mathrm{~A}>\mathrm{G}$ & Asn40Asp & $\begin{array}{l}891 \text { subjects } \\
(\mathrm{EA}, \mathrm{AA}, \mathrm{H})\end{array}$ & No significant differences & [31] \\
\hline & $N R G 1$ & 17664708 & $122-16329 \mathrm{C}>\mathrm{T}$ & Intron & $\begin{array}{l}738 \\
(\mathrm{AA}, \mathrm{EA})\end{array}$ & $\begin{array}{l}\text { Associated with cannabis } \\
\text { dependence in both AAs }\end{array}$ & {$[32]$} \\
\hline
\end{tabular}

EA European American, AA African American, CS Caucasians, $H$ - Hispanic, DSM Diagnostic and Statistical Manual of Mental Disorders, $C N R 1$ cannabinoid receptor 1, CNR2 cannabinoid receptor 2, $A B C B 1$ ATP-binding cassette subfamily B member $1, F A A H$ fatty acid amide hydrolase, $C O M T$ catechol-O-methyltransferase, GABRA2 gamma-aminobutyric acid type A receptor alpha2 subunit, OPRM1 opioid receptor mu 1, NRG1 neuregulin 1, THC tetrahydrocannabinol

CB2 receptors were than transfected into HEK293 cells. Through this study, it was demonstrated that the CB2 polymorphic receptors at both positions 63 and 316 are able to bind cannabinoid ligands and mediate signal transduction which may contribute to the etiology of certain diseases [22].

\subsubsection{Trpv1}

The TRPVI gene encodes the transient receptor potential action channel subfamily V member 1 (OMIM: 602076). So far, there have been no association studies that can demonstrate a relationship between the occurrence of TRPVI gene polymorphism and addiction to marijuana. Most research on the functioning of the endocannabinoid system (ECS) focuses on two well-characterized receptors: $\mathrm{CB} 1$ and $\mathrm{CB} 2$. In recent years, scientists have shown that this mechanism is much more complex and the ECS consisting of other types of receptors, which may affect the activity of ligands in many physiological processes [23]. Arnold et al. have described that $\Delta^{9}$ tetrahydrocannabinol ( $\Delta^{9} \mathrm{THC}$ ) binds to $\mathrm{CB} 1$ and $\mathrm{CB} 2$ receptors with similar affinities and behaves as a partial agonist, but it does not bind TRPV1 receptors. Cannabidiol (CBD) showed a more complex profile-simultaneous blockade of $\mathrm{CB} 2$ and TRPV1 significantly inhibited CBD-induced MDRl (multidrug resistance, also known as $A B C B 1$ gene, which was described in the next section) mRNA expression and both CB2 and TRPV1 antagonist were not effective when tested individually. CBD in its two enantiomeric forms showed 
no affinity for the $\mathrm{CB} 1$ and $\mathrm{CB} 2$ receptors (-)enantiomer or showed significant affinity for both receptor subtypes. It is, therefore, possible that the effectiveness of the CBD is related to inhibition of fatty acid amide hydrolase (FAAH) and elevates the level of anandamide (AEA). This would imply that AEA's simultaneous activation of CB2 and TRPV1 is necessary for increased MDRl mRNA expression following CBD exposure [23].

\subsubsection{Gpr55}

The human gene that encodes GPR55 protein is located on the long arm of chromosome 2 (2q37.1), encompasses 53,910 bases, and contains four exons (GeneCards, GeneBank, and Ensemble). The GPR55 receptor is consists of 319 amino acids and 7 hydrophobic domains. It belongs to a G-protein-coupled receptor superfamily, precisely to the rhodopsin-like (ClassA) family of GPCRs. The molecular mass of the protein is $36,637 \mathrm{Da}$. It is an integral membrane protein and its structure reminds structure of cannabinoid receptor. The GPR55 is de-orphanized as a CB receptor [24]. The amino acid sequence is the most similar to the GPR35 (27\%), P2Y (29\%), GPR23 (30\%), and CXCR4 (26\%) but also to CB2 (14.4\%) and CB1 $(13.5 \%)$ receptors [24]. It has been suggested that GPR55 is a novel CB receptor [25].

Expression of GPR55 (OMIM: 04107) in certain areas of the human brain is responsible for binding exo- and endogenous cannabinoids [26, 27]. From the functional analysis of the sole missense polymorphism c.584G $>\mathrm{T}$ (p.Gly195Val, rs3749073) in the GPR55 gene, which have a binding affinity for endocannabinoids, an association with anorexia nervosa has been observed [28].

\subsubsection{OPRM1 and GABRA2}

Many reports in the literature describe the possible association of polymorphisms with cannabis dependence [27, 29-32]. Particular attention is drawn to genes encoding opioid receptor (OPRM1, OMIM: 600018) and gammaaminobutyric acid (GABA) receptors (GABRA2, OMIM: 137140).

Agraval et al. suggest cannabis dependence association with SNPs in GABRA2 gene [33], in opposite to Lind group results [30]. They genotyped 11 SNPs within or flanking GABRA2 in 4597 subjects and showed no correlation with alcohol, smoking, or cannabis dependence [30].

OPRM1 gene encoding the mu opioid receptor (MOR) is also considered as candidate gene for cannabis use side effect. Gelernter and co-workers analyzed two polymorphisms affecting protein sequence in exon 1, Ala6Val and Asp40Asn in African American (AA), European American (EA), Hispanic, Japanese, Ethiopians, Bedouins, and
Ashkenazi Jews populations. The entire study group consisted of 891 subjects presented differences in the frequency of alleles between the AA and EA populations have been observed. For other studied subjects, they did not observe significant heterogeneity among. For all analyzed populations, neither polymorphism appears to be a direct risk factor for substance dependence [31].

\subsection{Transport and Action Genes}

\subsection{1 $A B C B 1$ and $A B C G 2$}

According to the DrugBank data base (www.drugbank.ca), there are mainly two membrane-associated proteins from the superfamily of ATP-binding cassette (ABC) transporters involved in cannabinoid transportation: $\mathrm{ABCB} 1$ and $\mathrm{ABCG} 2$, which play the role of multidrug resistance, especially ABCB1. Both proteins transport the molecules across extra- and intra-cellular membranes [34]. ABCBI gene, also known as multidrug resistance gene (MDRl), is located in the $7 \mathrm{q} 21$. It encodes P-glycoprotein (P-gp) and comprised of 28 exons [35]. $A B C B 1$ polymorphisms-the rs2032582 (c.2677G>T/A), rs1045642 (c.3435C>T), and rs1128503 (c.1236C $>$ T) are known to modify the drug pharmacokinetics, but there were not yet studied for their role in cannabis dependence [36]. Benyamina et al. try to determine if $A B C B 1$ rs1045642 polymorphism corresponds with cannabis dependence risk [37]. In this study, Caucasian patients diagnosed with isolated cannabis dependence $(n=40)$ with healthy controls $(n=40)$ were compared. Patients with cannabis dependence demonstrated significantly higher $3435 \mathrm{C}$ allele frequency $(62.5 \mathrm{vs}$ $43.8 \%, p=0.017)$ and CC genotype $[50$ vs $20 \%$, $p=0.005$, OR $=4.00(1.50-10.60)]$. These researchers postulate that $A B C B 1$ polymorphisms may affect $\triangle^{9} \mathrm{THC}$ distribution, its psychoactive effects, and individual vulnerability to dependence. Analyses indicated that the CC genotype was independently associated with cannabis dependence $[p=0.045, \mathrm{OR}=6.61(1.05-46.58)]$ and also has been associated with increased expression of P-gp, whereas the TT genotype reduces P-gp expression. It can lead to the conclusion that $\mathrm{CC}$ genotype may increase the tendency to cannabis dependence, while the TT genotype may increase the risk of cannabis-induced psychosis development [37].

$\triangle^{9} \mathrm{THC}$ has affinity for $A B C B 1$ and $A B C G 2$ gene products; notwithstanding, it is unknown whether they modulate the brain accumulation of $\Delta^{9} \mathrm{THC}$ and its functional effects on the central nervous system. Spiro et al. revealed that mice lacking of $A b c b 1$ and $A b c g 2$ proteins had higher brain $\Delta^{9} \mathrm{THC}$ levels and were more sensitive to cannabinoid-induced hypothermia than wild-type mice. As the authors say, these results indicate that ABCB1 and 
ABCG2 proteins prolong the brain disposition and hypothermic effects of $\Delta^{9} \mathrm{THC}$ which could be a new mechanism of genetic susceptibility to the psychoactive effects of cannabis and drug interactions (e.g., addiction and anxiety) between central nervous system therapies and cannabis [38]. So far, reports on role of $A B C$ transporter gene polymorphisms involved in genetic susceptibility to adverse psychoactive effects of $\Delta^{9} \mathrm{THC}$ or cannabis dependence are very slight. Perhaps, such research could contribute to the assessment of individual pharmacokinetic predisposition in response to cannabis use in conjunction with other genes that can modulate the pharmacodynamic actions of the drug.

\subsubsection{SLC6A4 and COMT}

Two other genetic polymorphisms have been associated with the neuroadaptive effects of $\Delta^{9} \mathrm{THC}$ on executive functions: 5-HTTLPR (c.199G $>$ A, rs2553) promoter polymorphism of the SLC6A4 gene (OMIM: 182138) and c. $472 \mathrm{G}>\mathrm{A}$ (p.Val158 Met, rs4680) polymorphism of the catechol-O-methyltransferase (COMT, OMIM: 116790) gene [27, 39]. An experimental challenge study has also shown that the COMT gene moderates the impact of $\Delta^{9} \mathrm{THC}$ on memory and sustained attention, such that individuals carrying the high-activity genotype GG in the position c.472 are more likely to show cannabis-induced cognitive deficits [40]. In healthy individuals, the neurobiological correlates of working memory encoding suggest an abnormally increased activation of the prefrontal-parietal-striatal network in homozygous GG vs AA. This network is also abnormally hyperactivated among cannabis users when performing working memory tests [41].

The 5-HTTLPR polymorphism is one of the main regulators of the serotonin transporter function [42] and the AA genotype (lower serotonin levels) has been consistently associated with poor decision-making skills in animals and humans [39, 43, 44]. Cannabis users carrying the genotype s/s 5-HTTLPR recorded worse results in the IGT decision test (Iowa Gambling Task) than the control group (noncannabis users) with the same genotype. It was also found that the presence of SLC6A4 and COMT gene polymorphisms in people taking cannabis has a moderate influence on the body's executive functions [39].

Other studies by Verdejo-Garcia et al. showed the impact of these polymorphisms on executive functions as moderate harmful effects of marijuana in young cannabis users. Cannabis users with the COMT c.472 (p.Val158M, rs4680) GG (Val/Val) genotype showed decreased attention compared to those in the control group with another genotype for this locus. Interestingly, the users carrying one $\mathrm{G}$ allele of the COMT gene committed more errors during the observation, monitoring, and handling of certain elements in relation to marijuana users but with the c.472 AA (Met/Met) genotype [39]. Henquet's research shows that the heterozygous c. $472 \mathrm{G}>\mathrm{A}(\mathrm{Val} / \mathrm{Met})$ of $C O M T$ gene exhibits an increased hallucinogenic effect on the action of cannabis than on patients with the G/G genotype [45].

Caspi et al. analyzed 803 individuals. Carriers of the COMT Val158 allele showed more often psychotic and schizophrenic symptoms when they used cannabis and, however, did not observed that in patients with two copies of the methionine allele [46]. Whereas Tunbridge et al. studied effect of COMT c.472G $>$ A (p.Val158Met) genotype on the cognitive and psychotic effects of $\Delta^{9} \mathrm{THC}$. They tested 78 suffered from paranoia participants (nonclinical cohort) in Digit Span Backwards task. $\Delta^{9}$ THC was administered intravenously in a double-blind, placebocontrolled manner. The results showed a correlation between the occurrence of genotype and study group on working memory and indicate a similar relationship that Verdo-Garcia received in his research, namely, that $\Delta^{9} \mathrm{THC}$ has an effect on the loss of efficiency for the COMT Val/ Val, but not Met carriers but interestingly not on psychotic experiences. The results suggest that COMT genotype can moderate the cognitive, but not the psychotic, effects of $\Delta^{9} \mathrm{THC}[47]$.

\subsection{Cannabinoids Metabolism Genes}

Cannabinoids metabolite formation is enzyme-depended, what was confirmed by simple experiment of synthetic cannabinoid FUBIMINA incubation for $3 \mathrm{~h}$ in hepatocyte samples and in buffer only [48]. The $\Delta^{9} \mathrm{THC}$ biotransformation is mainly based on oxidation, decarboxylation, and conjugation with glucuronic acid.

\subsubsection{CYPs Genes}

Cytochrome P450 (CYP, EC1.14.14.1) superfamily enzymes, namely, CYP3A4 (significant metabolic pathway for $\Delta^{9}$ THC and CBD) and CYP2C9 (significant contributor to $\triangle^{9} \mathrm{THC}$ metabolism) encoded by CYP2C9 (OMIM: 601130) and CYP3A4 (OMIM: 124010) genes, are predicted to play a major role in the primary metabolism of $\Delta^{9} \mathrm{THC}$, where THC serves as a substrate for these two CYP enzymes. Studies of $\Delta^{9} \mathrm{THC}, \mathrm{CBD}$, and cannabinol (CBN) inhibition and induction of CYP-450 indicate a low clinical importance with interactions with hemp use; however, there is a lack of relevant data on humans [49].

The $C Y P$ gene family includes 57 putatively functional genes and 58 pseudogenes in humans [50]. CYP gene mutation and polymorphism can lead to altered or cancelled enzyme activity. Phenotypically, it manifests as poor, intermediate, efficient, or ultrarapid drug metabolizers (UMs). To date, 60 alleles of the CYP2C9 gene (Human 
Cytochrome P450 Allele Nomenclature Committee, www. cypalleles.ki.se) have been described in the literature, with the two most frequently occurring being $C Y P 2 C 9 * 2$ (c.430C $>$ T, p.R144C) and $C Y P 2 C 9 * 3$ (c.1075A $>$ C, p.I359L), which lead to decreased enzyme activity and poor metabolism. In the case of the CYP3A4 gene, 26 alleles are known. CYP3A4*2,*11,*12,*17 are the most common cause of lower enzyme activity. $\Delta^{9} \mathrm{THC}$ biotransformation may occur via the following pathways: 7-OH- $\Delta^{8}$ THC by CYP3A4 enzyme, $11-\mathrm{OH}-\Delta^{9} \mathrm{THC}$ and 11-nor-9-carboxy- $\Delta^{9}$ THC by several UGT isoforms, 11-oxo- $\Delta^{8}$ THC by primarily CYP2C9; and some epoxide metabolites of $\Delta^{8}$ THC by epoxide hydrolase [49]. In vitro research data characterize cytochrome P-450 (CYP-450) enzymes as potential significant contributors to the primary metabolism of several exogenous cannabinoids: $\Delta^{8} \mathrm{THC}$ (CYP2C9, CYP3A4), CBD (CYP2C9, CYP3A4), CBN (CYP2C9, CYP3A4), JWH-018 (CYP1A2, CYP2C9), and AM2201 (CYP1A2, CYP2C9). CYP-450 enzymes may also contribute to secondary metabolism of $\Delta^{9}$ THC [49].

\subsubsection{UGTs Genes}

Cannabinoids are the subject of UDP-glucuronosyltransferase (UGT)-dependent glucuronidation. UGTs have been identified as capable of catalyzing both primary (CBD and $\mathrm{CBN})$ and secondary ( $\Delta^{9} \mathrm{THC}$, JWH-018, and JWH-073) metabolizers of some cannabinoids [49]. Mazur et al. demonstrated that the most important in this process are UGT1A9, UGT1A7, UGT1A8, and UGT1A10 enzymes encoded by genes with the same names: UGTIA9 (OMIM: 606434), UGT1A7 (OMIM: 606432), UGT1A8 (OMIM: 606433), and UGTIA1O (OMIM: 606435), respectively [51] and found that the glucuronidation of $\mathrm{CBN}$ and $\Delta^{9}$ THC-OH was carried out at similar rates by UGT1A9. In contrast, UGT1A10 was threefold more effective at CBN conjugation than $\Delta^{9}$ THC-OH. UGT1A1 and UGT1A3 demonstrated the only measurable activity toward $\Delta^{9} \mathrm{THC}$ $\mathrm{COOH}$. Moreover, $\mathrm{CBN}$ was glucuronidated at high levels by UGT1A10 and to a lesser extent by UGT1A7, UGT1A9, and UGT2B7. Activity toward CBD was limited, and the UGT1A9, UGT2B7, and UGT2B17 formed a minimal amount of a glucuronidated CBD product [51].

UGTIA genes are a part of a complex locus that encodes several UDP-glucuronosyltransferases with a specific sequence of the first exon and common exons 2-5. Most studies concern the UGTIA9 gene. The first exon encodes the substrate binding and regulation of gene expression is performed by means of its own promoter preceding the exon 1. A number of polymorphisms changes occur mainly in the promoter region and exon 1 of the gene UGTIA9 (https://www.pharmacogenomics.pha.ulaval.ca/ugt-allelesnomenclature). Previous studies have shown the variable activity of the UGT1A9 enzyme. The most important alleles of $U G T 1 A 9 * 3, * 4$, and $* 5$ lead to the reduction or elimination of the enzymatic activity of the protein product.

\subsection{Endocannabinoids Biosynthesis and Bioactivation Genes}

The two most studied endocannabinoids are anandamide (AEA) and 2-arachidonoylglycerol (2-AG). Changes in the AEA and 2-AG concentration in various tissues may be the cause of many diseases of the immune, neurological and neuropsychic system, as well as obesity, cancer, and cardiovascular diseases [52]. They initiate downstream signaling by binding to their target receptors: CB1, CB2, GPR55, and TRPV1 [53]. There are several paths for the formation and metabolism of AEA and 2-AG. 2-arachidonoylglycerol is produced by the hydrolysis of diacylglycerols DAGs, almost exclusively by one-selective DAG lipases $\alpha$ and $\beta$. AEA is metabolized by the fatty acid amide hydrolase (FAAH), whereas 2-AG does this via monoacylglycerol lipase (MGL). 2-AG is also metabolized to some extent by other lipases, such as $\alpha \beta$-hydrolase domain 6 (ABHD6) and 12 (ABHD12), as well as FAAH (Fig. 1).

Level of endocannabinoids is elevated at key sites involved in pain processing, such as neuropathic pain. Exploiting the potential therapeutic properties of cannabinoids may be possible by maximizing the effects of endocannabinoids in which are terminated by re-uptake and metabolism by different enzymes as FAAH, MAGL, and cyclooxygenase type 2 (COX-2). Prevention of metabolism or uptake of endocannabinoids would result in raising the level of these lipid compounds in the tissues and likely to affect the analgesic response in models of acute pain [54].

\subsubsection{FAAH}

Fatty acid amide hydrolase gene (FAAH; OMIM: 602935), located on the 1p35-34 human chromosome [55], encodes enzymes of ECS, which catabolize the conversion of both AEA and 2-AG to arachidonic acid, ethanolamine, or glycerol. A variant p.P129T in the $F A A H$ gene results in reduced enzyme activity among obesity patients [56]. Tyndale et al. demonstrated that inhibition of this enzyme, which decreases the intensity of endocannabinoid degradation, enhances analgesia not induced by opioids [57].

Other studies have shown a link between the $F A A H$ gene missense mutation c.385C $>$ A (p.Pro129Thr, rs324420), which results in the conversion of proline into threonine in exon 3. Many researchers have demonstrated that this sequence variation may be related to the dependence of 


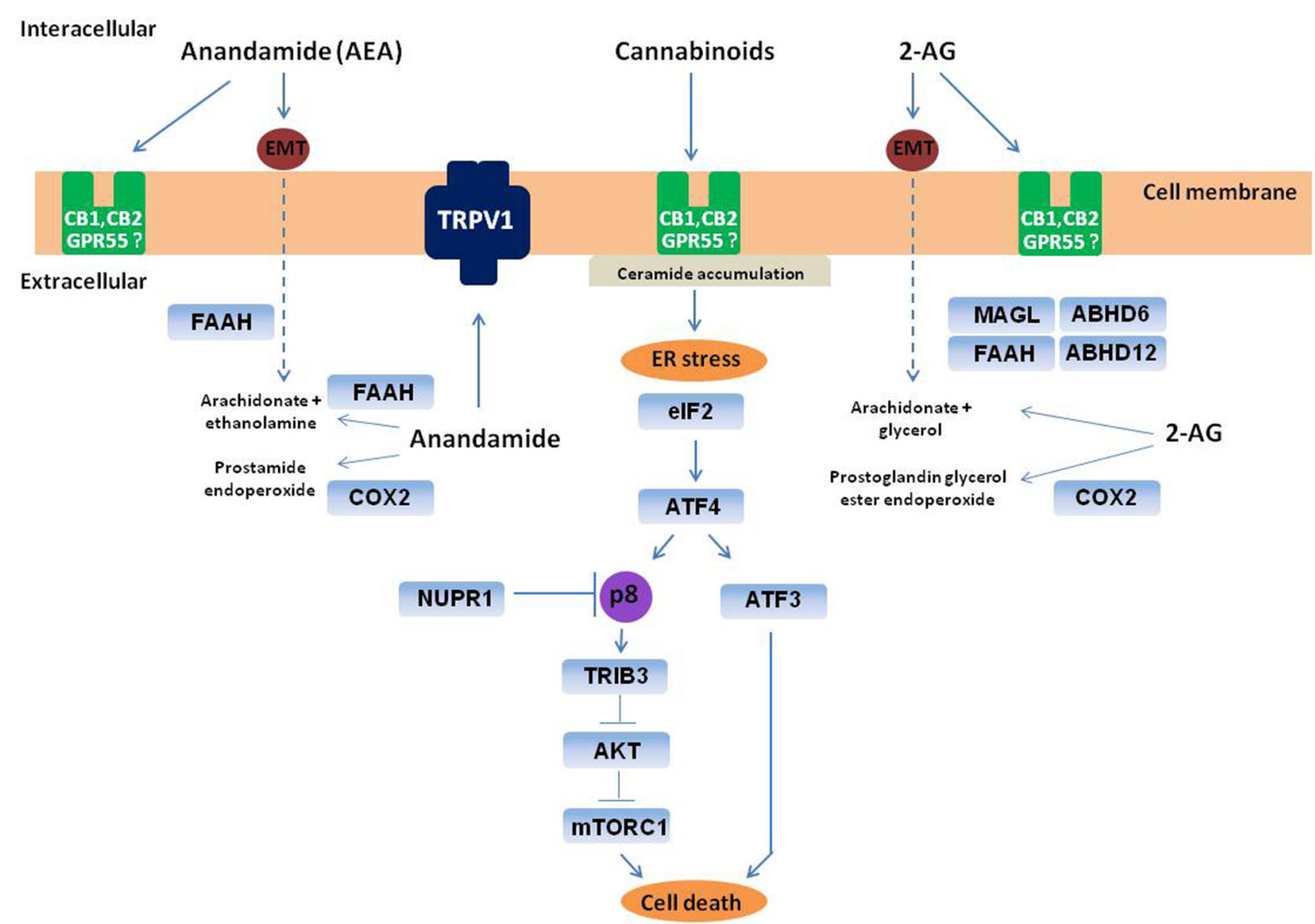

Fig. 1 Breakdown and action scheme of two endocannabinoids: AEA and 2-AG. After AEA and 2-AG cellular re-uptake, AEA is metabolized via FAAH, and 2-AG via MAGL as well as FAAH, ABHD6, and ABHD12. AEA and 2-AG under conditions, in which the activity of MAGL or FAAH is suppressed, might become substrates for COX2 and give rise to the corresponding hydroperoxy derivatives. AEA and 2-AG hydroperoxy derivates can then be converted to prostaglandin ethanolamides (prostamides) and prostaglandin glycerol esters, respectively, by various prostaglandin synthases. AEA also interacts with several non-cannabinoid receptors, such as TRPV1, GPR55 as well as 2-AG. Ceramide accumulation is also demonstrated, illustrating accumulation in tumor cells which

addiction in the Caucasian and African-American, but not in the case of the Japanese population and other Asian populations $[58,59]$. Sipe et al. showed that genotype AA in locus c.385 decreases the expression of the $F A A H$ gene in Caucasians and is associated with the abuse of alcohol and drugs $(\mathrm{OR}=4.54 ; 95 \% \mathrm{CI}=2.15-4.54)$ [60]. These results were also confirmed by Flanagan et al. $(\mathrm{OR}=3.2$; 95\% CI $=1.86-5.51$ ) [61]. The same genotype was associated by Tyndale et al. with the reduced likelihood of an impact on the dependence of $\Delta^{9} \mathrm{THC}(\mathrm{OR}=0.25 ; 95 \%$ $\mathrm{CI}=0.07-0.88)$ than for those carrying genotypes $\mathrm{CC}$ or CA [57]. mediates cannabinoid-induced apoptosis. ABHD6, ABHD12- $\alpha \beta-$ hydrolases domain-containing protein 6 and 12, respectively, $A E A$ anandamide, 2- $A G$ 2-arachidonoylglycerol, $A K T$ (also known as $P K B$ ) protein kinase $\mathrm{B}, m T O R C 1$ mechanistic target of rapamycin complex 1, ATF3 and ATF4 transcription activator of the integrated stress response, $C B 1, C B 2$ cannabinoid receptor, $C O X 2$ cyclooxygenase 2, eIF2 eukaryotic initiation factor $2 \alpha, E M T$ endocannabinoid membrane transporter, ER stress endoplasmic reticulum stress, FAAH fatty acid amide hydrolase, GPR55 orphan G-protein-coupled receptor, $M A G L$ monoacylglycerol lipase, $p 8$ (also known as Nupr1) small chromatin protein, TRIB3 human tribbles homolog 3, TRPV1 transient receptor potential action channel subfamily $\mathrm{V}$ member 1

\subsubsection{MAGL}

The monoglyceride lipase (MGL) enzyme encoded by the $M A G L$ gene is also responsible for the hydrolysis of 2-AG and other lipids (OMIM: 609699). Monoglyceride lipase is part of the endocannabinoid pathway, responsible for the inactivation of endogenous cannabinoids. It is suggested that ECS strengthens the action of drugs. This finding, in combination with other studies on the variability of genes involved in the endogenous cannabinoid system (such as GABRA2), may result in the relationship of dependence on cannabis being clarified [33, 62]. There is considerable 
evidence that $M A G L$ with $\mathrm{CB} 1$ and $F A A H$ plays a significant role in behavioral experiences related to $\Delta^{9} \mathrm{THC}$. Harismendy et al. [56] identified five rare and common regulatory variants in the population sequencing of the MAGL gene (c.47C $>\mathrm{T}$, p.Ser16Phe; c.256G $>\mathrm{A}$, p.Asp86Asn; c.427G $>$ A, p.Ala143Thr; c.819T $>$ G, p.Ile273Met; and c.919G $>$ A, p.Ala307Thr) associated with extreme obesity and metabolite level. These variants are described only in the HGMD $^{\circledR}$ Human Gene Mutation Database. In 2015, Carey et al. published a work which involves analysis of SNPs in six endocannabinoid genes (anabolism: DAGLA, DAGLB, and NAPEPLD, catabolism: $M A G L$ and $F A A H$, and binding: CNRI) in cannabis dependence symptoms. There was an evidence that $M A G L$ rs604300 (c.263-1443T>C) polymorphism interacts with early life adversity to predict threat-related basolateral amygdala habituation, a neural phenotype linked to the ECS and addiction $\left(\Delta R^{2}=0.013, p=0.047\right)$. This may be an evidence linking epigenetic modulation of $M A G L$ expression which affirms the results achieved in rodents assuming that 2-AG is metabolized by the enzyme encoded by the MAGL gene, as a causes of stress adaptation associated with cannabis dependence [63].

\subsubsection{ABHD6 and ABHD12}

It was discovered that 2-AG can be degraded to glycerol and arachidonic acid with the participation of FAAH and other hydrolytic enzymes, such as $\alpha \beta$-hydrolase domaincontaining protein 6 (ABHD6) and $\alpha \beta$-hydrolase domaincontaining protein 12 (ABHD12). Blankman et al. described that $\sim 85 \%$ of brain 2-AG hydrolase activity can be ascribed to MAGL, with the remaining $15 \%$ being mostly catalyzed by two hydrolytic enzymes, such as ABHD6 and ABHD12 [52, 64]. The authors speculate that MAGL, ABHD12, and ABHD6 may regulate different cellular or subcellular pools of 2-AG, thereby making unique contributions to endocannabinoid signaling in vivo [64]. Chromosomal localization, genes sequence of both ABHD6 (OMIM: 616966) and ABHD12 (OMIM: 613599) were characterized first in 2009 and 2010. There is a lack of functional investigations regarding their genetic variants; however, it is certainly an interesting field in the context of research on the effects of cannabinoids.

\subsubsection{COX2}

Recent research indicates a significant role of cyclooxygenase-2 (COX-2) in the mechanisms of intraneuronal CB1 signaling transduction and modulation of expression of COX2 (PTGS2, OMIM: 600262) and CNR1 genes. It has also been found that $\Delta^{9} \mathrm{THC}$ increases expression and activity of COX-2. Taurisano et al. genotyped 242 healthy subjects for $C O X 2$ and CNR1 gene variants, rs20417 and rs1406977, respectively. Results suggested specific interaction between $\mathrm{C}$ carriers of CNR1 gene, $\mathrm{C}$ carriers of COX2 as well as homozygous CNR1 TT and COX2 GG, which indicate the lower cortical response. It was associated with dorsolateral prefrontal cortex (DLPFC) activity, which in turn is correlated with frequency of cannabis use. The results suggest that the balance in the signaling COXCB1 pathway by genetic factors may influence the prefrontal activity during working memory process. This would mean that the use of cannabis affects the CNRI/ COX2 genes modulation of cortical processing in the cognitive process [65].

\subsubsection{MAPK14 and NGRI}

The Onwuameze group investigated the potential interactions between MAPK14 and CNRI gene variants [66]. MAPK14 (OMIM: 600289) is a family member of mitogenactivated protein kinase encoding the MAPK family factor, which is involved in various cellular processes, such as apoptosis (similar to CNR1). The study included 235 patients with schizophrenia, characterized by abuse/addiction to marijuana. The patients were analyzed in terms of MAPK14 SNPs; however, only the c.117-10981A $>\mathrm{G}$ (rs12199654) variant and the interaction of homozygotes AA vs marijuana abuse had a significant effect on the change in volume of white matter in the brain [66]. The effects of having MAPK14 rs12199654 variant on white matter volume deficits in the brain remained significant even when the simultaneous control by the CNRl gene and c. $* 2394 \mathrm{~A}>\mathrm{G}$ variant (rs12720071).

Other interesting observations relate to neuregulin 1 gene (NRG1, OMIM: 142445) encoding glycoprotein membrane that mediates cell-cell signaling. Han and colleagues performed a genome-wide linkage scan in 384 African American $(n=384)$ and European American ( $n=354$ ) for genetic studies of cannabis dependence. The results showed strong association between rs17664708 variant of NRGl gene and cannabis dependence in both European Americans $(\mathrm{OR}=1.38, p=0.02)$ and African Americans $[(\mathrm{OR})=2.93, p=0.0022]$. The next step which they have done was the replication of the association of rs17664708 with cannabis dependence in independent African American sample $(\mathrm{OR}=2.81, \quad p=0.0068)$. Common analysis of two African American samples showed a strong association between rs17664708 polymorphism and cannabis dependence in both the global $(p=0.00044)$ and the local ancestry $(p=0.00075)$. They suggest, therefore, that NRG1 may be likely susceptibility gene possessing cannabis dependence based on the evidence of linkage and associations replicated in two independent samples AA [32]. 


\section{Conclusions and Prospects in the Pharmacogenetics Context}

In recent years, we can observe increasing interest of the medicinal qualities of cannabis. There is an intense discussion of health benefits and risk of medical marihuana. However, everything varies over time. As of March 2015, 23 US states and the District of Columbia had medical marijuana laws in place [67]. However, in many countries in Europe and around the world, its use in medicine is unlawful. First, this is due to the many side effects and adverse use reactions of cannabinoids. On the other hand, we are witnessing incredible technological advances in molecular biology. Research carried out by molecular methods constitutes the most recent, rapidly growing field of laboratory tests. DNA sequence analysis and GWAS are important strategies for almost all biological research, also in the case of pharmacogenetics, which is based on candidate gene association studies.

Consistent and robust results in the context of genetic associations have not yet been shown so far, and for most of considered genetic variants, the observations are controversial (Table 1.) Moreover, previous studies mainly focused on CNRI gene which perhaps is dictated by relatively good knowledge of its function in endocannabinoid system. Molecular biology allows universal access to the comprehensive pharmacogenetic analysis of individual genomes. Current methods of sequencing already allow the whole genome DNA sequence to be recognized within a few days. There is a feeling that the next milestone, after legal acceptance of medical marijuana, will be intensive pharmacogenetic-oriented study of individual populations, which hopefully explain the previous contradictory results and identify in the future genetic markers to personalize cannabinoids treatment.

\section{Compliance with Ethical Standards}

Funding This work was supported financially by The National Centre for Research and Development (Grant Number INNOMED/I/ $11 / N C B R / 2014)$ from the Innovative Economy Operational Programme founds, in the framework of the European Regional Development Fund.

Conflict of interest Hryhorowicz S, Walczak M, Zakerska-Banaszak $\mathrm{O}$, Slomski R, and Skrzypczak-Zielińska M declare that there are no financial or other relationships, which could lead to the conflict of interest. The manuscript has been read and approved by all the authors. Each author believes that the manuscript represents honest work.

Open Access This article is distributed under the terms of the Creative Commons Attribution-NonCommercial 4.0 International License (http://creativecommons.org/licenses/by-nc/4.0/), which permits any noncommercial use, distribution, and reproduction in any medium, provided you give appropriate credit to the original author(s) and the source, provide a link to the Creative Commons license, and indicate if changes were made.

\section{References}

1. Moore TH, Zammit S, Lingford-Hughes A, Barnes TR, Jones PB, Burke M, Lewis G. Cannabis use and risk of psychotic or affective mental health outcomes: a systematic review. Lancet. 2007;370:319-28.

2. Hashibe M, Straif K, Tashkin DP, Morgenstern H, Greenland S, Zhang ZF. Epidemiologic review of marijuana use and cancer risk. Alcohol. 2005;35:265-75.

3. Grant I, Gonzalez R, Carey CL, Natarajan L, Wolfson T. Nonacute (residual) neurocognitive effects of cannabis use: a metaanalytic study. J Int Neuropsychol Soc. 2003;9:679-89.

4. Wang T, Collet JP, Shapiro S, Ware MA. Adverse effects of medical cannabinoids: a systematic review. CMAJ. 2008;178: 1669-78.

5. Gadzicki D, Müller-Vahl K, Stuhrmann M. A frequent popymorphism in the coding exon of the human cannabinoid receptor (CNR1) gene. Mol Cell Probes. 1999;13:321-3.

6. Zhang PW, Ishiguro H, Ohtsuki T, Hess J, Carillo F, Walther D, Onaivi ES, Arinami T, Uhl GR. Human cannabinoid receptor 1: $5^{\prime}$ exons, candidate regulatory regions, polymorphisms, haplotypes and association with polysubstance abuse. Mol Psychiatry. 2004;9:916-31.

7. De Fonseca Fr, Del Arco I, Bermundez-Silva FJ, Bilbao A, Cippitelli A, Navarro M. The endocannabinoid system: physiology and pharmacology. Alcohol Alcohol. 2005;40:2-14.

8. Di Marzo V, Matias I. Endocannabinoid control of food intake and energy balance. Nat Neurosci. 2005;8:585-9.

9. Agrawal A, Wetherill L, Dick DM, Xuei X, Hinrichs A, Hesselbrock V, Kramer J, Nurnberger JI Jr, Schuckit M, Bierut LJ, Edenberg HJ, Foroud T. Evidence for association between polymorphisms in the cannabinoid receptor 1 (CNR1) gene and cannabis dependence. Am J Med Genet B Neuropsychiatr Genet. 2009; 150B:736-40.

10. Comings DE, Muhleman D, Gade R, Johnson P, Verde R, Saucier G, MacMurray J. Cannabinoid receptor gene (CNR1): association with i.v. drug use. Mol Psychiatry. 1997;2:161-8.

11. Li T, Liu X, Zhu ZH, Zhao J, Hu X, Ball DM, Sham PC, Collier DA. No association between (AAT) $n$ repeats in the cannabinoid receptor gene (CNR1) and heroin abuse in a Chinese population. Mol Psychiatry. 2000;5:128-30.

12. Heller D, Schneider U, Seifert J, Cimander KF, Stuhrmann M. The cannabinoid receptor gene (CNR1) is not affected in German i.v. drug users. Addict Biol. 2001;6:183-7.

13. Covault J, Gelernter J, Kranzler H. Association study of cannabinoid receptor gene (CNR1) alleles and drug dependence. Mol Psychiatry. 2001;6:501-2.

14. Hopfer CJ, Young SE, Purcell S, Crowley TJ, Stallings MC, Corley RP, Rhee SH, Smolen A, Krauter K, Hewitt JK, Ehringer MA. Cannabis receptor haplotype associated with fewer cannabis dependence symptoms in adolescents. Am J Med Genet B Neuropsychiatr Genet. 2006;141B:895-901.

15. Herman AI, Kranzler HR, Cubells JF, Gelernter J, Covault J. Association study of the CNR1 gene exon 3 alternative promoter region polymorphisms and substance dependence. Am J Med Genet B Neuropsychiatr Genet. 2006;141:499-503.

16. Verweij KJ, Zietsch BP, Liu JZ, Medland SE, Lynskey MT, Madden PA, Agrawal A, Montgomary GW, Heath AC, Martin NG. No association of candidate genes with cannabis use in a large sample of Australian twin families. Addict Biol. 2012;17:687-90. 
17. Hartman CA, Hopfer CJ, Haberstick B, Rhee SH, Crowley TJ, Corley RP, Hewitt JK, Ehringer MA. The association between cannabinoid receptor 1 gene (CNR1) and cannabis dependence symptoms in adolescents and young adults. Drug Alcohol Depend. 2009;104:11-6.

18. Bühler KM, Huertas E, Echeverry-Alzate V, Giné E, Moltó E, Montoliu L, López-Moreno JA. Risky alkohol consumption in young people is associated with the fatty acid amide hydrolase gene polymorphism C385A and affective rating of drug pictures. Mol Genet Genom. 2014;289:279-89.

19. Zuo L, Kranzler HR, Luo X, Covault J, Gelernter J. CNR1 variation modulates risk for drug and alcohol dependence. Biol Psychiatry. 2007;62:616-26.

20. Haughey HM, Marshall E, Schacht JP, Louis A, Hutchison KE. Marijuana withdrawal and craving: influence of the cannabinoid receptor $1(\mathrm{CNR} 1)$ and fatty acid amide hydrolase (FAAH) genes. Addiction. 2008;103:1678-86.

21. Ishiguro H, Iwasaki S, Teasenfitz L, Higuchi S, Horiuchi Y, Saito $\mathrm{T}$, Arinami T, Onaivi ES. Involvement of cannabinoid CB2 receptor in alcohol preference in mice and alcoholism in humans. Pharmacogenom J. 2007;7:380-5.

22. Carrasquer A, Nebane NM, Williams WM, Song ZH. Functional consequences of nonsynonymous single nucleotide polymorphisms in the CB2 cannabinoid receptor. Pharmacogenet Genom. 2010;20:157-66.

23. Arnold JC, Hone P, Holland ML, Allen JD. CB2 and TRPV1 receptors mediate cannabinoid actions on MDR1 expression in multidrug resistant cells. Pharmacol Rep. 2012;64:751-7.

24. Shore DM, Reggio PH. The therapeutic potential of orphan GPCRs, GPR35 and GPR55. Front Pharmacol. 2015;6:69.

25. Mackie K, Stella N. Cannabinoid receptors and endocannabinoids: evidence for new players. AAPS J. 2006;8:E298-306.

26. Ryberg E, Larsson N, Sjogren S, Hjorth S, Hermansson NO, Leonova J, Elebring T, Nilsson K, Drmota T, Greasley PJ. The orphan receptor GPR55 is a novel cannabinoid receptor. Br J Pharmacol. 2007;152:1092-101.

27. Agrawal A, Lynskey MT. Candidate genes for cannabis use disorders: findings. Chall Dir Addict. 2009;104:518-32.

28. Ishiguro H, Onaivi ES, Horiuchi Y, Imai K, Komaki G, Ishikawa T, Suzuki M, Watanabe Y, Ando T, Higuchi S, Arinami T. Functional polymorphism in the GPR55 gene is associated with anorexia nervosa. Synapse. 2011;65:103-8.

29. Agrawal A, Pergadia ML, Saccone SF, Lynskey MT, Wang JC, Martin NG, Statham D, Henders A, Campbell M, Garcia R, Broms U, Todd RD, Goate AM, Rice J, Kaprio J, Heath AC, Montgomery GW, Madden PA. An autosomal linkage scan for cannabis use disorders in the nicotine addiction genetics project. Arch Gen Psychiatry. 2008;65:713-21.

30. Lind PA, Macgregor S, Agrawal A, Montgomery GW, Heath AC, Martin NG, Whitfield JB. The role of GABRA2 in alcohol dependence, smoking, and illicit drug use in an Australian population sample. Alcohol Clin Exp Res. 2008;32:1721-31.

31. Gelernter J, Kranzler H, Cubells J. Genetics of two mu opioid receptor gene (OPRM1) exon I polymorphisms: population studies, and allele frequencies in alcohol- and drug-dependent subjects. Mol Psychiatry. 1999;4:476-83.

32. Han S, Yang BZ, Kranzler HR, Oslin D, Anton R, Farrer LA, Gelernter J. Linkage analysis followed by association show NRG1 associated with cannabis dependence in African Americans. Biol Psychiatry. 2012;72:637-44.

33. Agrawal A, Edenberg HJ, Foroud T, Bierut LJ, Dunne G, Hinrichs AL, Nurnberger JI, Crowe R, Kuperman S, Schuckit MA, Begleiter H, Porjesz B, Dick DM. Association of GABRA2 with drug dependence in the collaborative study of the genetics of alcoholism sample. Behav Genet. 2006;36:640-50.
34. Tournier N, Chevillard L, Megarbane B, Pirnay S, Scherrmann $\mathrm{JM}$, Decleves X. Interaction of drugs of abuse and maintenance treatments with human P-glycoprotein $(\mathrm{ABCB} 1)$ and breast cancer resistance protein (ABCG2). Int J Neuropsychopharmacol. 2010;13:905-15.

35. Hoffmeyer S, Burk O, von Richter O, Arnold HP, Brockmöller J, Johne A, Cascorbi I, Gerloff T, Roots I, Eichelbaum M. Brinkmann U Functional polymorphisms of the human multidrug-resistance gene: multiple sequence variations and correlation of one allele with P-glycoprotein expression and activity in vivo. Proc Natl Acad Sci USA. 2000;97:3473-8.

36. Rui-Jian Y, Ting-Ting L, Yi-Fang W, Wei-Shan C. Single nucleotide polymorphisms of ABCB1 gene and response to etanercept treatment in patients with ankylosing spondylitis in a Chinese Han population. Med (Baltimore). 2017;96:e5929.

37. Benyamina A, Bonhomme-Faivre L, Picard V, Sabbagh A, Richard D, Blecha L, Rahioui H, Karila L, Lukasiewicz M, Farinotti R, Picard V, Marill C, Reynaud M. Association between ABCB1 C3435T polymorphism and increased risk of cannabis dependence. Prog Neuropsychopharmacol Biol Psychiatry. 2009;33:1270-4.

38. Spiro AS, Wong A, Boucher A, Arnold JC. Enhanced brain disposition and effects of $\Delta^{9}$-tetrahydrocannabinol in P-glycoprotein and breast cancer resistance protein knockout mice. PLoS One. 2012;7:e35937.

39. Verdejo-García A, Fagundo AB, Cuenca A, Rodriguez J, Cuyás E, Langohr K, de Sola Llopis S, Civit E, Farré M, Peña-Casanova $\mathrm{J}$, de la Torre R. COMT val158met and 5-HTTLPR genetic polymorphisms moderate executive control in cannabis users. Neuropsychopharmacology. 2013;38:1598-606.

40. Henquet C, Rosa A, Krabbendam L, Papiol S, Fananás L, Drukker M, Ramaekers JG, van Os J. An experimental study of catechol-o-methyltransferase Val158Met moderation of delta-9tetrahydrocannabinol-induced effects on psychosis and cognition. Neuropsychopharmacology. 2006;31:2748-57.

41. Jager G, Block RI, Luijten M, Ramsey NF. Cannabis use and memory brain function in adolescent boys: a cross-sectional multicenter functional magnetic resonance imaging study. J Am Acad Child Adolesc Psychiatry. 2010;49:561-72.

42. Greenberg BD, Tolliver TJ, Huang SJ, Li Q, Bengel D, Murphy DL. Genetic variation in the serotonin transporter promoter region affects serotonin uptake in human blood platelets. Am J Med Genet. 1999;88:83-7.

43. Homberg JR, van den Bos R, den Heijer E, Suer R, Cuppen E. Serotonin transporter dosage modulates long-term decisionmaking in rat and human. Neuropharmacology. 2008;55:80-4.

44. Sonuga-Barke EJ, Kumsta R, Schlotz W, Lasky-Su J, Marco R, Miranda A, Mulas F, Oades RD, Banaschewski T, Mueller U, Andreou P, Christiansen H, Gabriels I, Uebel H, Kuntsi J, Franke B, Buitelaar J, Ebstein R, Gill M, Anney R, Roeyers H, Rothenberger A, Sergeant J, Steinhausen HC, Asherson P, Faraone SV. A functional variant of the serotonin transporter gene (SLC6A4) moderates impulsive choice in attention-deficit/hyperactivity disorder boys and siblings. Biol Psychiatry. 2011;70:230-6.

45. Henquet C, Rosa A, Delespaul P, Papiol S, Fananás L, van Os J, Myin-Germeys I. COMT ValMet moderation of cannabis-induced psychosis: a momentary assessment study of 'switching on' hallucinations in the flow of daily life. Acta Psychiatr Scand. 2009; 119:156-60.

46. Caspi A, Moffitt TE, Cannon M, McClay J, Murray R, Harrington H, Taylor A, Arseneault L, Williams B, Braithwaite A, Poulton R, Craig IW. Moderation of the effect of adolescent-onset cannabis use on adult psychosis by a functional polymorphism in the catechol-O-methyltransferase gene: longitudinal evidence of a 
gene $\mathrm{X}$ environment interaction. Biol Psychiatry. 2005;57:1117-27.

47. Tunbridge EM, Dunn G, Murray RM, Evans N, Lister R, Stumpenhorst K, Harrison PJ, Morrison PD, Freeman D. Genetic moderation of the effects of cannabis: catechol-O-methyltransferase (COMT) affects the impact of $\Delta 9$-tetrahydrocannabinol (THC) on working memory performance but not on the occurrence of psychotic experiences. J Psychopharmacol. 2015;29:1146-51.

48. Diao X, Scheidweiler KB, Wohlfarth A, Zhu M, Pang S, Huestis MA. Strategies to distinguish new synthetic cannabinoid FUBIMINA (BIM-2201) intake from its isomer THJ-2201: metabolism of FUBIMINA in human hepatocytes. Forensic Toxicol. 2016;34:256-67.

49. Stout SM, Cimino NM. Exogenous cannabinoids as substrates, inhibitors, and inducers of human drug metabolizing enzymes: a systematic review. Drug Metab Rev. 2014;46:86-95.

50. Nelson DR, Zeldin DC, Hoffman SM, Maltais LJ, Wain HM, Nebert DW. Comparison of cytochrome P450 (CYP) genes from the mouse and human genomes, including nomenclature recommendations for genes, pseudogenes and alternative-splice variants. Pharmacogenetics. 2004;14:1-18.

51. Mazur A, Lichti CF, Prather PL, Zielinska AK, Bratton SM, Gallus-Zawada A, Finel M, Miller GP, Radomińska-Pandya A, Moran JH. Characterization of human hepatic and extrahepatic UDP-glucuronosyltransferase enzymes involved in the metabolism of classic cannabinoids. Drug Metab Dispos. 2009;37: 1496-504.

52. Di Marzo V. Targeting the endocannabinoid system: to enhance or reduce? Nat Rev Drug Discov. 2008;7:438-55.

53. Maccarrone M, Guzmán M, Mackie K, Doherty P, Harkany T. Programming of neural cells by (endo)cannabinoids: from physiological rules to emerging therapies. Nat Rev Neurosci. 2014;15:786-801.

54. Jhaveri MD, Richardson D, Chapman VB. Endocannabinoid metabolism and uptake: novel targets for neuropathic and inflammatory pain. J Pharmacol. 2007;152:624-32.

55. Ben-Shabat S, Fride E, Sheskin T, Tamiri T, Rhee MH, Vogel Z, Bisogno T, De Petrocellis L, Di Marzo V, Mechoulam R. An entourage effect: inactive endogenous fatty acid glycerol esters enhance 2-arachidonoyl-glycerol cannabinoid activity. Eur J Pharmacol. 1998;353:23-31.

56. Harismendy O, Bansal V, Bhatia G, Nakano M, Scott M, Wang X, Dib C, Turlotte E, Sipe JC, Murray SS, Deleuze JF, Bafna V, Topol EJ, Frazer KA. Population sequencing of two endocannabinoid metabolic genes identifies rare and common regulatory variants associated with extreme obesity and metabolite level. Genome Biol. 2010;11:R118.

57. Tyndale RF, Payne JI, Gerber AL, Sipe JC. The fatty acid amide hydrolase C385A (P129T) missense variant in cannabis users: studies of drug use and dependence in Caucasians. Am J Med Genet B Neuropsychiatr Genet. 2007;144:660-6.
58. Morita Y, Ujike H, Tanaka Y, Uchida N, Nomura A, Ohtani K, Kishimoto M, Morio A, Imamura T, Sakai A, Inada T, Harano M, Komiyama T, Yamada M, Sekine Y, Iwata N, Iyo M, Sora I, Ozaki N, Kuroda S. A nonsynonymous polymorphism in the human fatty acid amide hydrolase gene did not associate with either methamphetamine dependence or schizophrenia. Neurosci Lett. 2005;376:182-7.

59. Iwasaki S, Ishiguro H, Higuchi S, Onaivi ES, Arinami T. Association study between alcoholism and endocannabinoid metabolic enzyme genes encoding fatty acid amide hydrolase and monoglyceride lipase in a Japanese population. Psychiatr Genet. 2007; $17: 215-20$

60. Sipe JC, Chiang K, Gerber AL, Beutler E, Cravatt BF. A missense mutation in human fatty acid amide hydrolase associated with problem drug use. Proc Natl Acad Sci USA. 2002;99: 8394-9.

61. Flanagan JM, Gerber AL, Cadet JL, Beutler E, Sipe JC. The fatty acid amide hydrolase $385 \mathrm{~A} / \mathrm{A}$ (P129T) variant: haplotype analysis of an ancient missense mutation and validation of risk for drug addiction. Hum Genet. 2006;120:581-8.

62. Hopfer CJ, Lessem JM, Hartman CA, Stallings MC, Cherny SS, Corley RP, Hewitt JK, Krauter KS, Mikulich-Gilbertson SK, Rhee SH, Smolen A, Young SE, Crowley TJ. A genome-wide scan for loci influencing adolescent cannabis dependence symptoms: evidence for linkage on chromosomes 3 and 9. Drug Alcohol Depend. 2006;89:34-41.

63. Carey CE, Agrawal A, Zhang B, Conley ED, Degenhardt L, Heath AC, Li D, Lynskey MT, Martin NG, Montgomery GW, Wang T, Bierut LJ, Hariri AR, Nelson EC, Bogdan R. Monoacylglycerol lipase (MGLL) polymorphism rs604300 interacts with childhood adversity to predict cannabis dependence symptoms and amygdala habituation: evidence from an endocannabinoid system-level analysis. J Abnorm Psychol. 2015;124:860-77.

64. Blankman JL, Simon GM, Cravatt BF. A comprehensive profile of brain enzymes that hydrolyze the endocannabinoid 2-arachidon-oylglycerol. Chem Biol. 2007;14:1347-56.

65. Taurisano P, Antonucci LA, Fazio L, Rampino A, Romano R, Porcelli A, Masellis R, Colizzi M, Quarto T, Torretta S, Di Giorgio A, Pergola G, Bertolino A, Blasi G. Prefrontal activity during working memory is modulated by the interaction of variation in $\mathrm{CB} 1$ and $\mathrm{COX} 2$ coding genes and correlates with frequency of cannabis use. Cortex. 2016;81:231-8.

66. Onwuameze OE, Nam KW, Epping EA, Wassink TH, Ziebell S, Andreasen NC, Ho BC. MAPK14 and CNR1 gene variant interactions: effects on brain volume deficits in schizophrenia patients with marijuana misuse. Psychol Med. 2013;43:619-31.

67. Hill KP. Medical marijuana for treatment of chronic pain and other medical and psychiatric problems: a clinical review. JAMA. 2015;313:2474-83. 